\title{
Genetic Variability of Isolates of Ramulispora sorghi From Cáceres-MT, Brazil
}

\author{
A. V. M. Duarte ${ }^{1}$, C. L. Correa ${ }^{2,3}$, M. A. A. Barelli ${ }^{1,2}$, B. W. Zago ${ }^{1}$, N. L. Sander ${ }^{1}$, T. S. Guimarães ${ }^{2}$, D. D. Silva ${ }^{4}$, \\ V. P. da Silva ${ }^{1} \&$ R. Felipin-Azevedo ${ }^{2,5}$ \\ ${ }^{1}$ Postgraduate Program in Biodiversity and Biotechnology, Bionorte Network, Cáceres, Brazil \\ ${ }^{2}$ Postgraduate Program in Genetics and Plant Breeding, Universidade do Estado de Mato Grosso, Cáceres, MT, \\ Brazil \\ ${ }^{3}$ National Postdoctoral Program, CAPES, Brazil \\ ${ }^{4}$ Empresa Brasileira de Pesquisa Agropecuária, Centro Nacional de Pesquisa em Milho e Sorgo, Sete Lagoas, \\ MG, Brazil \\ ${ }^{5}$ Regional Scientific Development Scholarship Program, FAPEMAT/CNPq, Brazil \\ Correspondence: R. Felipin-Azevedo, Post Graduate Program in Genetics and Plant Breeding, PGMP Network, \\ Universidade do Estado de Mato Grosso, Mato Grosso, Brazil. Tel: 55-659-9615-2717. E-mail: \\ rafhaelfelipin@gmail.com
}

$\begin{array}{lrr}\text { Received: April 6, } 2019 & \text { Accepted: May 25, } 2019 & \text { Online Published: July 15, } 2019 \\ \text { doi:10.5539/jas.v11n10p250 } & \text { URL: https://doi.org/10.5539/jas.v11n10p250 }\end{array}$

The research is financed by Fundação de Amparo a Pesquisa do Estado de Mato Grosso-FAPEMAT, Conselho Nacional de Desenvolvimento Científico e Tecnológico-CNPq and Coordenação de Aperfeiçoamento de Pessoal de Nivel Superior-CAPES.

\begin{abstract}
Among the most produced cereals worldwide, sorghum (Sorghum bicolor (L.) Moench), presents low productivity in Brazil, mainly due to the occurrence of diseases, with a prominence of sooty stripe, caused by the fungus Ramulispora sorghi, until then considered a secondary disease, has increased its incidence and severity, especially in conditions of high humidity and temperature. The most efficient means of control is the use of resistant cultivars, in this sense, studies on the genetic variability of the fungus through molecular markers are of great importance for the breeding programs of sorghum. The objective of this work was to evaluate the genetic variability in isolates of Ramulispora sorghi belonging to the mycoteca of the Laboratory of Genetic Resources \& Biotechnology of the Universidade do Estado de Mato Grosso, campus of Cáceres, via molecular markers of the ISSR type. The results indicate the existence of genetic variability among the isolates of $R$. sorghi. The Polymorphic Information Content (PIC) showed that the primers were classified as medium informational with an average value of 0.27. 71 polymorphic fragments were formed considering the 40 isolates of $R$. sorghi, which presented the value of $\mathrm{k}=2$, represent the differentiation of the isolates into two distinct clusters. The genetic dissimilarity measures were estimated by the Coefficient of $\mathrm{Nei}$ and $\mathrm{Li}$, where the combination between the isolates B107/16 (15) and B103/15 (16) obtained the smallest magnitude $(0,12)$ and the combinations between isolates B111/16 (2) and S114/15 (33), S316/15 (3) and S114/15 (33), B115/16 (4) and S114/15 (33), B118/16 (6) and S114/15 (33) were more dissimilar (1,00). The "UPGMA" method provided a breakdown of the 40 isolates into 4 distinct groups. The Cophenetic Correlaction Coefficient (CCC) presented significant value with $r=0,84$. The Tocher's optimization method allowed the 40 isolates to be distributed in 10 different groups. These results provide relevant information on the genetic variability among the 40 isolates of $R$. sorghi analyzed. In addition, they indicate that fungus have a wide genetic diversity, and have been recurring in different regions of Brazil and the world, and thus, larger studies become essential for more effective control measures.
\end{abstract}

Keywords: genetic variability, sorghum disease, genetic resistance 


\section{Introduction}

The sorghum (Sorghum bicolor (L.) Moench) occupies a prominent position as to its importance among the most consumed/produced cereals in the world, together with wheat, maize, rice and barley (FAO, 2019; Nida et al., 2019). In Brazil, its production has gained prominence in recent years, being cultivated different types of sorghum (grain, forage, broom, saccharine and biomass), which are mainly destined for animal feed and biodiesel production (Neumann et al., 2004; Almorade \& Hady, 2009; Teixeira et al., 2014). However, Brazilian productivity is still considered low, mainly due to occurrences of diseases, among them the sooty stripe of sorghum, caused by the fungus Ramulispora sorghi (Ellis \& Everh.) Olive and Lefebvre (1946) (Ribas et al., 2008; Cota et al., 2013; CONAB, 2019).

The sooty stripe is a disease whose etiological agent is the fungus Ramulispora sorghi that causes necrotic foliar lesions, promoting the reduction of the photosynthetic area and, consequently, reducing the productive capacity of the plant (Williams et al., 1978; Bandyopadhyay, 2000; Ferreira et al., 2007; Brady et al., 2011; Little et al., 2018).

The emergence and development of $R$. sorghi is favored by conditions of high temperature and humidity, the fungus survives in the soil, or in cultural remains in the form of microsclerodes and, when there are favorable conditions, they produce conidia, which can be dispersed through rains and winds, causing significant losses in sorghum crops (Brady et al., 2011; Cúdom et al., 2016).

The first report of the disease was in 1903, in the United States and, like the planting of culture, the disease has been present in different regions of the world (Thomas et al., 1993). In the Brazilian scenario, the occurrence of the sooty stripe of sorghum has increased mainly in succession crops to summer crops and where high temperature and humidity conditions are present during the crop cycle (Ferreira et al., 2007). Thus, susceptible cultivars may present low productivity due to the appearance of the fungus $R$. sorghi (Little et al., 2018).

In 2016 there was the first report of the ramulispora spot in the city of Cáceres, state of Mato Grosso, Brazil, in the harvest of 2013/2014, by Silva (2016), where parts of leaf lesions were isolated from 25 grain sorghum genotypes and 16 saccharin sorghum genotypes and, according to the Kock Postulate, the occurrence of the disease was confirmed (Silva, 2016).

Among the methods of disease control, crop rotation and fungicide treatment stand out, but the most efficient and safe means is the use of genetically resistant cultivars, in this sense, studies on the genetic variability of phytopathogens have been developed with molecular markers of the ISSR type with different races of fungi (Talamini et al., 2006). In this way, the use of molecular markers has been one of the alternatives to obtain more information about the fungus and can indicate resistant cultivars for the control of the disease, mainly, through breeding programs that aim at the genetic resistance of plants (Silva, 2009).

The quantification of the genetic variability of the pathogenic fungi helps to plan the strategies of selection of resistant plants more effectively (Oliveira, 2015). Therefore, the objective of this work was to evaluate the genetic variability in isolates of $R$. sorghi belonging to the library of the Laboratory of Genetic Resources and Biotechnology (LRG\&B) of Universidade do Estado de Mato Grosso (UNEMAT), university campus of Cáceres, via molecular markers of the ISSR type.

\section{Material and Methods}

The library of $R$. sorghi located in the Laboratory of Genetic Resources and Biotechnology of Universidade do Estado de Mato Grosso (UNEMAT), university campus of Cáceres, Brazil, is composed of 40 isolates, 39 of which were collected from genotypes of saccharin sorghum (S) and 1 of biomass sorghum (B) that presented symptoms of the disease in the plantations of the years 2015 to 2017. The seeds for the plantations were provided through a partnership with Embrapa Agrossilvipastoril, located in the city of Sinop, state of Mato Grosso. These experiments were conducted in randomized blocks with three replicates, whose plot was composed of four rows of $5.0 \mathrm{~m}$ in length, spaced at $0.70 \mathrm{~m}$ between rows, with only the two central rows considered as a useful plot. Once the disease was identified in the sorghum genotype, the material was sent to the Laboratory of Genetic Resources and Biotechnology for isolation and storage. The another isolate was obtained from the National Center for Research on Maize and Sorghum (CNPSo) of the Brazilian Agricultural Research Corporation (Embrapa).

The isolates that compose the library were: S326/15 (1), B111/16 (2), S316/15 (3), B115/16 (4), B311/16 (5), B118/16 (6), B319/16 (7), B131/16 (8), B108/16 (9), B101/16 (10), B122/15 (11), B122/16 (12), B105/16 (13), EMB03 (14), B107/16 (15), B103/15 (16), B113/16 (17), B216/16 (18), B114/16 (19), B107/15 (20), B116/15 (21), B202/16 (22), B106/16 (23), B122/16(24), B117/16 (25), B109/16 (26), B226/16 (27), B106/15 (28), 
B226/15 (29), B105/15 (30), B120/15 (31), B101/15 (32), S114/15 (33), B104/17 (34), B112/17 (35), B201/17 (36), B115/17 (37), B206/17 (38), B225/17 (39) and B209/17 (40), where the letter identifies the type of sorghum and is followed by the numbering corresponds to the number of the genotype and the year of collection and the numbering in parentheses corresponds to the number of the isolate in the analyzes of the results.

For analysis of the genetic variability, the isolates were removed from the storage medium of the library and transferred to Petri dishes containing oatmeal and agar medium, in the ratio of $30 \mathrm{~g}$ of oatmeal to $20 \mathrm{~g}$ of agar, submitted to controlled temperature conditions $\left(27 \pm 2{ }^{\circ} \mathrm{C}\right)$ for 7 days to obtain the mycelial mass (Gooding \& Lucas, 1959).

The preparation of the genomic material of the fungi of $R$. sorghi was carried out by means of maceration of the mycelial mass of the fungi in a mortar with the addition of Polyvinylpyrrolidone (PVP) in the presence of liquid nitrogen until a fine powder was obtained. Extraction of genomic DNA followed the recommendations of the Wizard ${ }^{\circledR}$ Genomic DNA Purification Kit (Promega, Madison, WI).

The obtained genomic material was submitted to amplifications, through PCR reactions (Polymerase Chain Reaction) using nine primers: AP1; AP3; AP4; CAC, UBC 881; UBC 817; UBC 850; UBC 880 and (GTG) 6 , for the 40 isolates. PCR amplification reactions were prepared to a final volume of $20 \mu \mathrm{L}$ containing: $2 \mu \mathrm{l} 10 \mathrm{x}$ buffer, $1 \mu 1 \mathrm{MgCl}_{2}(2.5 \mathrm{mM}), 4 \mu \mathrm{dNTP}(2 \mathrm{mM}), 3.0 \mu \mathrm{l}$ primer $(2 \mathrm{mM}), 1 \mu \mathrm{L}$ formamide, $0.2 \mu \mathrm{L}$ Taq DNA polymerase and q.s.p. MilliQ water, in a thermocycler, where the reactions were subjected to the initial denaturation conditions at $94{ }^{\circ} \mathrm{C}$ for 3 minutes, 35 cycles of amplification, each presented at $94{ }^{\circ} \mathrm{C}$ to 30 seconds, specific TMs of the primers, at 30 seconds, $72{ }^{\circ} \mathrm{C}$, at 30 seconds and final extension at $72{ }^{\circ} \mathrm{C}$ for 5 minutes. PCR products were stained with GelRed + Blue Juice mix in a ratio of 5:1 and then electrophoresed at $80 \mathrm{~V}$ for approximately 1 hour and 30 minutes on agarose gel $(1.5 \%)$. The marker used to define the pattern of the amplified fragments was the $100 \mathrm{bp}$ DNA Ladder, with posterior visualization in photodocumentator.

DNA fragments generated by ISSR markers on agarose gels were detected as presence (1) or absence (0) of bands by means of the software Gel Quant Express, allowing the transformation of the bands formed in the agarose gel in values of quantity of base pairs (AMPL Software, 2015). These presence or absence information were used to quantify the genetic diversity of the loco or PIC (polymorphic content index) where the information contained in locus $\mathrm{p}_{\mathrm{i}}$ is given by the frequency of the allele $\mathrm{p}$ in loco $\mathrm{p}_{\mathrm{i}}$, calculated by equation: $\mathrm{PIC}=1-\Sigma_{\mathrm{i}} \mathrm{p}_{\mathrm{i}}{ }^{2}$ and the information acquired by the primer $\mathrm{p}_{\mathrm{ij}}$ is given by the frequency of the allele $\mathrm{p}$ of loco $\mathrm{i}$, in the primer $\mathrm{j}$, calculated by equation: PIC primer $=1-\Sigma_{\mathrm{i}} \cdot \Sigma_{\mathrm{j}} \mathrm{p}_{\mathrm{ij}}{ }^{2}$ (Rezende et al., 2009; Silva et al., 2016).

From this information, we obtained the analysis of the population structure of the isolates of $R$. sorghi that was carried out using the program Structure (Pritchard et al., 2000), which has the purpose of estimating the proportion of alleles that came from each of the groups where the variable $\mathrm{K}$ is equivalent to the number of genetically distinct and predefined populations (Evanno et al., 2005).

Based on the presence and absence data, a matrix based on the Nei and Li coefficient was generated, obtaining the dissimilarity of the evaluated isolates. This matrix was used to generate the dendrogram by the "Unweighted Pair Group Method using Arithmetic averages" (UPGMA), obtained through the R software and in the clustering by the Tocher's Optimization method obtained by the Genes software (Cruz, 2006).

\section{Results}

The results obtained through the genetic analysis of the isolates of $R$. sorghi showed the existence of genetic variability in the collected isolates. The values obtained by the analysis of the Polimorphic Information Content (PIC) showed that the primers used in the study revealed the existence of genetic variability among the isolates, classified as medium information with an average value of 0.27 . The values obtained ranged from 0.21 for the primer AP4 to 0.33 for the primers $(\mathrm{GTG})_{6}$ and AP1 (Table 1). Thus, the molecular markers used for this study are in the range of results that contribute to the understanding of the genetic variability of the 40 isolates of $R$. sorghi from this research. 
Table 1. ISSR markers were manipulated in the amplification of 40 isolates of Ramulispora sorghi with their respective sequences, Melting temperatures (TM in ${ }^{\circ} \mathrm{C}$ ) and polymorphic information content (PIC)

\begin{tabular}{llll}
\hline Primers & Sequence $\left(5^{\prime}-3^{\prime}\right)$ & Tm $\left({ }^{\circ} \mathrm{C}\right)$ & PIC \\
\hline UBC 881 & $(\mathrm{GGGT})_{3}$ TG & 64.4 & 0.26 \\
$(\mathrm{GTG})_{6}$ & $(\mathrm{GTG})_{6}$ & 64.4 & 0.33 \\
AP1 & $(\mathrm{CAG})_{5}$ & 58.8 & 0.33 \\
CAC & $(\mathrm{CAC})_{5}$ & 58.8 & 0.28 \\
UBC 850 & $(\mathrm{GT})_{8} \mathrm{YC}$ & 56.4 & 0.26 \\
AP3 & $(\mathrm{GACAC})_{3}$ & 56.4 & 0.28 \\
UBC 880 & $(\mathrm{GGAGA})_{3}$ & 56.2 & 0.26 \\
AP4 & $(\mathrm{GACA})_{4}$ & 50.0 & 0.21 \\
UBC 817 & $(\mathrm{CA})_{8} \mathrm{~A}$ & 43.2 & 0.26 \\
\hline Average & & 50.25 & 0.27 \\
\hline
\end{tabular}

Based on the electrophoretic pattern, we performed the analysis to obtain the best genetic grouping of the isolates, using the Structure software, based on Bayesian statistics, which infers the ideal number of groups ( $\Delta \mathrm{k})$ that best represents the study population. 71 polymorphic fragments were formed considering the 40 isolates of $R$. sorghi, which presented the value of $\mathrm{k}=2$, in wich, this number of groups considered the best grouping for the structure of the population. The distinction in two groups is observed where the highest peak for the change of value is in the value of $\Delta \mathrm{K}$ equal to 2 (Figure 1).

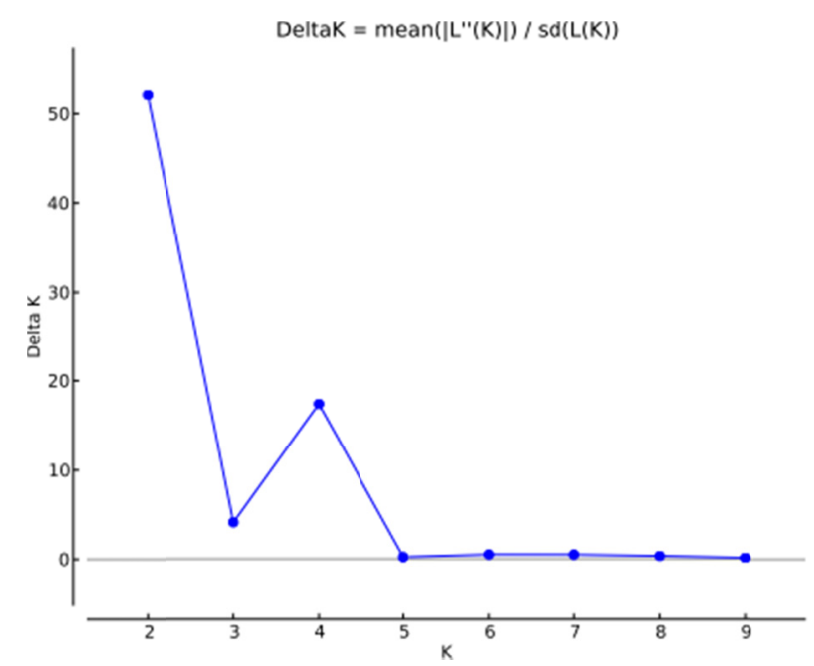

Figure 1. Graphical representation of the number of groups $(\Delta \mathrm{k})$ of the monosporic isolates of Ramulispora sorghi considering the nine ISSR markers by means of the Structure software

The results of the population structure analysis of the 40 isolates of $R$. sorghi demonstrated in Figure 2, clearly represent the differentiation of the isolates in two distinct clusters, the first formed by 16 isolates, which were collected in the harvest of 2015/2016 and the second cluster formed by 24 isolates collected in the crop 2015/2016, 2016/2017 and also by the isolate from Embrapa. The subdivisions of the isolates are shown in the vertical lines that separate the individuals in the bar plot diagram of the Structure program (Pritchard et al., 2000) in which it is possible to observe that the columns of different colors indicate the different clusters. The introgressors represent the genetic similarity of the isolates of different colors in the same bar of the bar plot, corresponding to $35 \%$ of the total. 


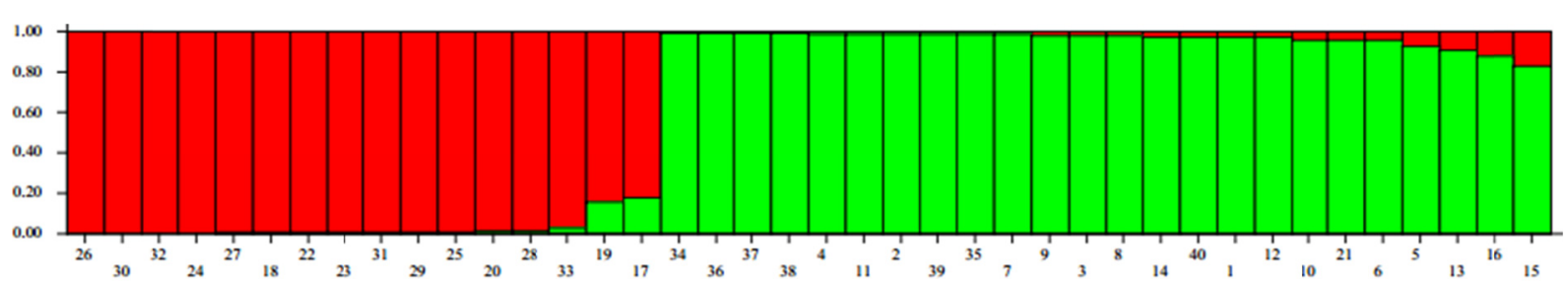

Figure 2. Monosporic isolates of Ramulispora sorghi, represented vertically and divided according to color and/or group according to molecular data obtained

The genetic dissimilarity measures of the 40 isolates of $R$. sorghi were estimated from the Coefficient of Nei and $\mathrm{Li}$ and are represented in Table 2, where the combination between isolates B107/16 (15) and B103/15 (16) obtained the lowest magnitude of dissimilarity (0.12) and the combinations between isolates B111/16 (2) and S114/15 (33), S316/15 (3) and S114/15 (33), B115/16 (4) and S114/15 (33), B118/16 (6) and S114/15 (33) were more dissimilar (1.00).

Table 2. Dissimilarity matrix among the 40 isolates of Ramulispora sorghi based on the Coefficient of $N e i$ and $L i$ using ISSR fragments

\begin{tabular}{|c|c|c|c|c|c|c|c|c|c|c|c|c|c|c|c|}
\hline Is & 1 & 2 & 3 & 4 & 5 & 6 & 7 & 8 & 9 & 10 & 11 & 12 & 13 & 14 & 15 \\
\hline 1 & 0.00 & 0.61 & 0.55 & 0.62 & 0.35 & 0.40 & 0.61 & 0.39 & 0.52 & 0.67 & 0.51 & 0.52 & 0.29 & 0.48 & 0.60 \\
\hline 2 & & 0.00 & 0.47 & 0.38 & 0.26 & 0.22 & 0.42 & 0.36 & 0.50 & 0.70 & 0.46 & 0.36 & 0.50 & 0.45 & 0.52 \\
\hline 3 & & & 0.00 & 0.52 & 0.58 & 0.47 & 0.76 & 0.60 & 0.79 & 0.72 & 0.68 & 0.67 & 0.62 & 0.56 & 0.79 \\
\hline 4 & & & & 0.00 & 0.47 & 0.33 & 0.51 & 0.52 & 0.64 & 0.69 & 0.53 & 0.47 & 0.47 & 0.48 & 0.59 \\
\hline 5 & & & & & 0.00 & 0.20 & 0.42 & 0.41 & 0.56 & 0.69 & 0.54 & 0.45 & 0.25 & 0.47 & 0.54 \\
\hline 6 & & & & & & 0.00 & 0.40 & 0.22 & 0.50 & 0.55 & 0.33 & 0.37 & 0.37 & 0.41 & 0.30 \\
\hline 7 & & & & & & & 0.00 & 0.35 & 0.50 & 0.63 & 0.40 & 0.41 & 0.47 & 0.56 & 0.45 \\
\hline 8 & & & & & & & & 0.00 & 0.33 & 0.56 & 0.45 & 0.36 & 0.23 & 0.41 & 0.42 \\
\hline 9 & & & & & & & & & 0.00 & 0.69 & 0.65 & 0.71 & 0.43 & 0.70 & 0.54 \\
\hline 10 & & & & & & & & & & 0.00 & 0.45 & 0.43 & 0.60 & 0.67 & 0.52 \\
\hline 11 & & & & & & & & & & & 0.00 & 0.23 & 0.42 & 0.48 & 0.48 \\
\hline 12 & & & & & & & & & & & & 0.00 & 0.39 & 0.42 & 0.24 \\
\hline 13 & & & & & & & & & & & & & 0.00 & 0.46 & 0.33 \\
\hline 14 & & & & & & & & & & & & & & 0.00 & 0.53 \\
\hline 15 & & & & & & & & & & & & & & & 0.00 \\
\hline 16 & & & & & & & & & & & & & & & \\
\hline 17 & & & & & & & & & & & & & & & \\
\hline 18 & & & & & & & & & & & & & & & \\
\hline 19 & & & & & & & & & & & & & & & \\
\hline 20 & & & & & & & & & & & & & & & \\
\hline 21 & & & & & & & & & & & & & & & \\
\hline 22 & & & & & & & & & & & & & & & \\
\hline 23 & & & & & & & & & & & & & & & \\
\hline 24 & & & & & & & & & & & & & & & \\
\hline 25 & & & & & & & & & & & & & & & \\
\hline 26 & & & & & & & & & & & & & & & \\
\hline 27 & & & & & & & & & & & & & & & \\
\hline 28 & & & & & & & & & & & & & & & \\
\hline 29 & & & & & & & & & & & & & & & \\
\hline 30 & & & & & & & & & & & & & & & \\
\hline 31 & & & & & & & & & & & & & & & \\
\hline 32 & & & & & & & & & & & & & & & \\
\hline 33 & & & & & & & & & & & & & & & \\
\hline 34 & & & & & & & & & & & & & & & \\
\hline 35 & & & & & & & & & & & & & & & \\
\hline 36 & & & & & & & & & & & & & & & \\
\hline 37 & & & & & & & & & & & & & & & \\
\hline 38 & & & & & & & & & & & & & & & \\
\hline 39 & & & & & & & & & & & & & & & \\
\hline 40 & & & & & & & & & & & & & & & \\
\hline
\end{tabular}


Table 2. Continued

\begin{tabular}{|c|c|c|c|c|c|c|c|c|c|c|c|c|c|c|c|}
\hline Is $^{\top}$ & 16 & 17 & 18 & 19 & 20 & 21 & 22 & 23 & 24 & 25 & 26 & 27 & 28 & 29 & 30 \\
\hline 1 & 0.58 & 0.50 & 0.53 & 0.41 & 0.52 & 0.45 & 0.63 & 0.56 & 0.46 & 0.53 & 0.58 & 0.53 & 0.58 & 0.67 & 0.61 \\
\hline 2 & 0.50 & 0.53 & 0.60 & 0.56 & 0.62 & 0.56 & 0.57 & 0.67 & 0.62 & 0.63 & 0.69 & 0.68 & 0.63 & 0.68 & 0.74 \\
\hline 3 & 0.78 & 0.82 & 0.76 & 0.67 & 0.74 & 0.50 & 0.70 & 0.80 & 0.82 & 0.82 & 0.85 & 0.88 & 0.78 & 0.72 & 0.85 \\
\hline 4 & 0.59 & 0.46 & 0.61 & 0.55 & 0.63 & 0.61 & 0.58 & 0.66 & 0.58 & 0.64 & 0.69 & 0.63 & 0.57 & 0.59 & 0.73 \\
\hline 5 & 0.52 & 0.48 & 0.46 & 0.43 & 0.51 & 0.55 & 0.50 & 0.48 & 0.47 & 0.52 & 0.47 & 0.54 & 0.47 & 0.57 & 0.56 \\
\hline 6 & 0.37 & 0.38 & 0.39 & 0.30 & 0.39 & 0.27 & 0.43 & 0.58 & 0.43 & 0.47 & 0.50 & 0.48 & 0.52 & 0.58 & 0.67 \\
\hline 7 & 0.45 & 0.50 & 0.60 & 0.60 & 0.57 & 0.63 & 0.67 & 0.66 & 0.52 & 0.63 & 0.63 & 0.67 & 0.57 & 0.58 & 0.61 \\
\hline 8 & 0.40 & 0.45 & 0.49 & 0.44 & 0.56 & 0.45 & 0.56 & 0.64 & 0.49 & 0.56 & 0.64 & 0.50 & 0.52 & 0.62 & 0.65 \\
\hline 9 & 0.58 & 0.73 & 0.64 & 0.57 & 0.70 & 0.65 & 0.72 & 0.73 & 0.63 & 0.76 & 0.76 & 0.63 & 0.69 & 0.76 & 0.74 \\
\hline 10 & 0.57 & 0.45 & 0.43 & 0.54 & 0.55 & 0.67 & 0.57 & 0.67 & 0.53 & 0.54 & 0.61 & 0.57 & 0.52 & 0.60 & 0.70 \\
\hline 11 & 0.52 & 0.46 & 0.57 & 0.42 & 0.63 & 0.40 & 0.57 & 0.61 & 0.53 & 0.50 & 0.63 & 0.58 & 0.56 & 0.61 & 0.69 \\
\hline 12 & 0.24 & 0.21 & 0.44 & 0.45 & 0.52 & 0.55 & 0.53 & 0.60 & 0.46 & 0.45 & 0.55 & 0.50 & 0.57 & 0.66 & 0.61 \\
\hline 13 & 0.33 & 0.41 & 0.35 & 0.33 & 0.50 & 0.42 & 0.56 & 0.52 & 0.31 & 0.48 & 0.48 & 0.52 & 0.50 & 0.59 & 0.48 \\
\hline 14 & 0.50 & 0.40 & 0.47 & 0.39 & 0.50 & 0.41 & 0.48 & 0.48 & 0.44 & 0.51 & 0.62 & 0.51 & 0.52 & 0.58 & 0.62 \\
\hline 15 & 0.12 & 0.31 & 0.41 & 0.51 & 0.35 & 0.50 & 0.44 & 0.48 & 0.39 & 0.43 & 0.45 & 0.41 & 0.45 & 0.54 & 0.43 \\
\hline 16 & 0.00 & 0.33 & 0.42 & 0.56 & 0.50 & 0.66 & 0.52 & 0.55 & 0.43 & 0.49 & 0.51 & 0.46 & 0.54 & 0.60 & 0.49 \\
\hline 17 & & 0.00 & 0.19 & 0.28 & 0.30 & 0.62 & 0.32 & 0.37 & 0.27 & 0.20 & 0.25 & 0.35 & 0.35 & 0.43 & 0.33 \\
\hline 18 & & & 0.00 & 0.13 & 0.25 & 0.54 & 0.24 & 0.25 & 0.16 & 0.23 & 0.15 & 0.26 & 0.24 & 0.38 & 0.33 \\
\hline 19 & & & & 0.00 & 0.29 & 0.33 & 0.26 & 0.32 & 0.27 & 0.26 & 0.18 & 0.29 & 0.30 & 0.43 & 0.44 \\
\hline 20 & & & & & 0.00 & 0.56 & 0.21 & 0.19 & 0.21 & 0.25 & 0.27 & 0.30 & 0.25 & 0.37 & 0.41 \\
\hline 21 & & & & & & 0.00 & 0.49 & 0.31 & 0.56 & 0.57 & 0.59 & 0.46 & 0.47 & 0.59 & 0.63 \\
\hline 22 & & & & & & & 0.00 & 0.14 & 0.23 & 0.26 & 0.26 & 0.22 & 0.19 & 0.31 & 0.38 \\
\hline 23 & & & & & & & & 0.00 & 0.21 & 0.30 & 0.21 & 0.21 & 0.24 & 0.20 & 0.24 \\
\hline 24 & & & & & & & & & 0.00 & 0.26 & 0.22 & 0.25 & 0.30 & 0.31 & 0.29 \\
\hline 25 & & & & & & & & & & 0.00 & 0.14 & 0.29 & 0.28 & 0.32 & 0.26 \\
\hline 26 & & & & & & & & & & & 0.00 & 0.27 & 0.24 & 0.27 & 0.25 \\
\hline 27 & & & & & & & & & & & & 0.00 & 0.14 & 0.27 & 0.32 \\
\hline 28 & & & & & & & & & & & & & 0.00 & 0.19 & 0.26 \\
\hline 29 & & & & & & & & & & & & & & 0.00 & 0.21 \\
\hline 30 & & & & & & & & & & & & & & & 0.00 \\
\hline 31 & & & & & & & & & & & & & & & \\
\hline 32 & & & & & & & & & & & & & & & \\
\hline 33 & & & & & & & & & & & & & & & \\
\hline 34 & & & & & & & & & & & & & & & \\
\hline 35 & & & & & & & & & & & & & & & \\
\hline 36 & & & & & & & & & & & & & & & \\
\hline 37 & & & & & & & & & & & & & & & \\
\hline 38 & & & & & & & & & & & & & & & \\
\hline 39 & & & & & & & & & & & & & & & \\
\hline 40 & & & & & & & & & & & & & & & \\
\hline
\end{tabular}


Table 2. Continued

\begin{tabular}{|c|c|c|c|c|c|c|c|c|c|c|}
\hline $\mathrm{Is}^{\mathrm{T}}$ & 31 & 32 & 33 & 34 & 35 & 36 & 37 & 38 & 39 & 40 \\
\hline 1 & 0.64 & 0.58 & 0.65 & 0.80 & 0.76 & 0.76 & 0.81 & 0.78 & 0.74 & 0.71 \\
\hline 2 & 0.70 & 0.72 & 1.00 & 0.75 & 0.94 & 0.80 & 0.76 & 0.77 & 0.85 & 0.88 \\
\hline 3 & 0.79 & 0.83 & 1.00 & 0.80 & 0.87 & 0.87 & 0.74 & 0.82 & 0.75 & 0.83 \\
\hline 4 & 0.74 & 0.75 & 1.00 & 0.51 & 0.84 & 0.72 & 0.63 & 0.71 & 0.56 & 0.68 \\
\hline 5 & 0.65 & 0.56 & 0.67 & 0.86 & 0.87 & 0.93 & 0.81 & 0.88 & 0.92 & 0.85 \\
\hline 6 & 0.58 & 0.63 & 1.00 & 0.80 & 0.90 & 0.80 & 0.70 & 0.83 & 0.65 & 0.85 \\
\hline 7 & 0.68 & 0.58 & 0.80 & 0.78 & 0.89 & 0.77 & 0.83 & 0.80 & 0.81 & 0.79 \\
\hline 8 & 0.62 & 0.60 & 0.63 & 0.74 & 0.94 & 0.77 & 0.75 & 0.78 & 0.77 & 0.76 \\
\hline 9 & 0.76 & 0.71 & 0.85 & 0.76 & 0.83 & 0.83 & 0.85 & 0.83 & 0.78 & 0.90 \\
\hline 10 & 0.67 & 0.72 & 0.70 & 0.55 & 0.67 & 0.57 & 0.58 & 0.56 & 0.56 & 0.66 \\
\hline 11 & 0.71 & 0.66 & 0.75 & 0.68 & 0.70 & 0.55 & 0.81 & 0.65 & 0.68 & 0.70 \\
\hline 12 & 0.65 & 0.66 & 0.65 & 0.71 & 0.82 & 0.70 & 0.77 & 0.68 & 0.68 & 0.83 \\
\hline 13 & 0.57 & 0.50 & 0.75 & 0.80 & 0.72 & 0.86 & 0.73 & 0.88 & 0.75 & 0.76 \\
\hline 14 & 0.60 & 0.62 & 0.62 & 0.60 & 0.67 & 0.66 & 0.62 & 0.57 & 0.63 & 0.62 \\
\hline 15 & 0.47 & 0.46 & 0.71 & 0.84 & 0.86 & 0.92 & 0.77 & 0.80 & 0.83 & 0.80 \\
\hline 16 & 0.47 & 0.58 & 0.60 & 0.83 & 0.83 & 0.83 & 0.72 & 0.79 & 0.93 & 0.84 \\
\hline 17 & 0.46 & 0.39 & 0.56 & 0.68 & 0.76 & 0.76 & 0.75 & 0.68 & 0.79 & 0.70 \\
\hline 18 & 0.33 & 0.39 & 0.48 & 0.71 & 0.63 & 0.75 & 0.63 & 0.62 & 0.69 & 0.64 \\
\hline 19 & 0.41 & 0.43 & 0.53 & 0.68 & 0.60 & 0.68 & 0.63 & 0.66 & 0.71 & 0.61 \\
\hline 20 & 0.30 & 0.36 & 0.52 & 0.80 & 0.65 & 0.84 & 0.69 & 0.64 & 0.57 & 0.63 \\
\hline 21 & 0.60 & 0.57 & 0.73 & 0.72 & 0.71 & 0.77 & 0.75 & 0.73 & 0.55 & 0.71 \\
\hline 22 & 0.38 & 0.37 & 0.50 & 0.74 & 0.65 & 0.78 & 0.70 & 0.63 & 0.68 & 0.67 \\
\hline 23 & 0.31 & 0.23 & 0.33 & 0.83 & 0.69 & 0.80 & 0.79 & 0.70 & 0.67 & 0.72 \\
\hline 24 & 0.33 & 0.30 & 0.46 & 0.77 & 0.65 & 0.78 & 0.64 & 0.67 & 0.62 & 0.67 \\
\hline 25 & 0.33 & 0.26 & 0.44 & 0.76 & 0.78 & 0.77 & 0.71 & 0.74 & 0.73 & 0.64 \\
\hline 26 & 0.29 & 0.26 & 0.40 & 0.78 & 0.74 & 0.84 & 0.68 & 0.76 & 0.79 & 0.66 \\
\hline 27 & 0.32 & 0.28 & 0.39 & 0.64 & 0.64 & 0.73 & 0.74 & 0.67 & 0.62 & 0.58 \\
\hline 28 & 0.35 & 0.19 & 0.50 & 0.61 & 0.72 & 0.66 & 0.76 & 0.68 & 0.69 & 0.47 \\
\hline 29 & 0.29 & 0.18 & 0.48 & 0.70 & 0.77 & 0.71 & 0.71 & 0.74 & 0.62 & 0.67 \\
\hline 30 & 0.22 & 0.06 & 0.50 & 0.79 & 0.79 & 0.84 & 0.80 & 0.81 & 0.87 & 0.73 \\
\hline 31 & 0.00 & 0.18 & 0.36 & 0.86 & 0.76 & 0.90 & 0.72 & 0.78 & 0.82 & 0.74 \\
\hline 32 & & 0.00 & 0.40 & 0.88 & 0.77 & 0.88 & 0.83 & 0.74 & 0.77 & 0.66 \\
\hline 33 & & & 0.00 & 0.89 & 0.81 & 0.90 & 0.81 & 0.67 & 0.78 & 0.64 \\
\hline 34 & & & & 0.00 & 0.51 & 0.30 & 0.29 & 0.43 & 0.52 & 0.33 \\
\hline 35 & & & & & 0.00 & 0.54 & 0.52 & 0.40 & 0.45 & 0.38 \\
\hline 36 & & & & & & 0.00 & 0.51 & 0.48 & 0.50 & 0.49 \\
\hline 37 & & & & & & & 0.00 & 0.40 & 0.63 & 0.44 \\
\hline 38 & & & & & & & & 0.00 & 0.50 & 0.29 \\
\hline 39 & & & & & & & & & 0.00 & 0.45 \\
\hline 40 & & & & & & & & & & 0.00 \\
\hline
\end{tabular}

Note. ${ }^{1}$ Isolates: 1) $\mathrm{S} 326 / 15$, 2) $\mathrm{B} 111 / 16$, 3) $\left.\left.\left.\left.\left.\mathrm{S} 316 / 15,4\right) \mathrm{B} 115 / 16,5\right) \mathrm{B} 311 / 16,6\right) \mathrm{B} 118 / 16,7\right) \mathrm{B} 319 / 16,8\right)$ $\mathrm{B} 131 / 16$, 9) $\mathrm{B} 108 / 16$, 10) $\mathrm{B} 101 / 16$, 11) B122/15, 12) $\mathrm{B} 122 / 16,13) \mathrm{B} 105 / 16,14) \mathrm{EMB} 03,15) \mathrm{B} 107 / 16,16)$ $\mathrm{B} 103 / 15$, 17) B113/16, 18) B216/16, 19) B114/16, 20) B107/15, 21) B116/15, 22) B202/16, 23) B106/16, 24) $\mathrm{B} 122 / 16,25) \mathrm{B} 117 / 16,26) \mathrm{B} 109 / 16,27) \mathrm{B} 226 / 16,28) \mathrm{B} 106 / 15,29) \mathrm{B} 226 / 15,30) \mathrm{B} 105 / 15,31) \mathrm{B} 120 / 15,32)$ B101/15, 33) S114/15, 34) B104/17, 35) B112/17, 36) B201/17, 37) B115/17, 38) B206/17, 39) B225/17 and 40) B209/17.

Another method analyzed was the Unweighted Pair Group Method with Arithmetic Mean (UPGMA), which, with a significant cut of just over $60 \%$, which resulted in a division of the 40 isolates into 4 distinct groups, where group I allocated eight isolates , being them: B101/16 (10), B225/17 (39), B112/17 (35), B206/17 (38), B209/17 (40), B201/17 (36), B104/17 (34) and B115/17 (37). The second and third groups were composed of only one isolate each S316/15 (3) and B108/16 (9), respectively (Figure 3).

Group IV was subdivided into subgroups consisting of 15 isolates each: IV a: S114/15 (33), B120/15 (31), B226/15 (29), B105/15 (30), B101/15 (32), B216/16 (18), B114/16 (19), B117/16 (25), B109/16 (26), B226/16 (27), B106/15 (28), B122/16 (24), B107/15 (20), B202/16 (22) and B106/16 (23); And the group IV b: B115/16 
(4), EMB03 (14) and B116/15 (21), B111/16 (2), B311/16 (5), B118/16 (6), S326/15 (1), B131/16 (8), B105/16 (13), B107/16 (15), B103/15 (16), B122/16 (12), B113/16 (17), B319/16 (7) and B122/15 (11).

The Cophenetic Correlation Coefficient (CCC), applied to the clustering method by the $\mathrm{T}$ test, presented a significant value $\mathrm{r}=0.84^{* *}$, demonstrating the reliability in the dissimilarity matrix relation and the dendrogram. According to Gonçalves et al. (2014), the greater the proximity of the CCC value with 1.0 the better the representation of the dissimilarity matrix in the form of dendrogram.

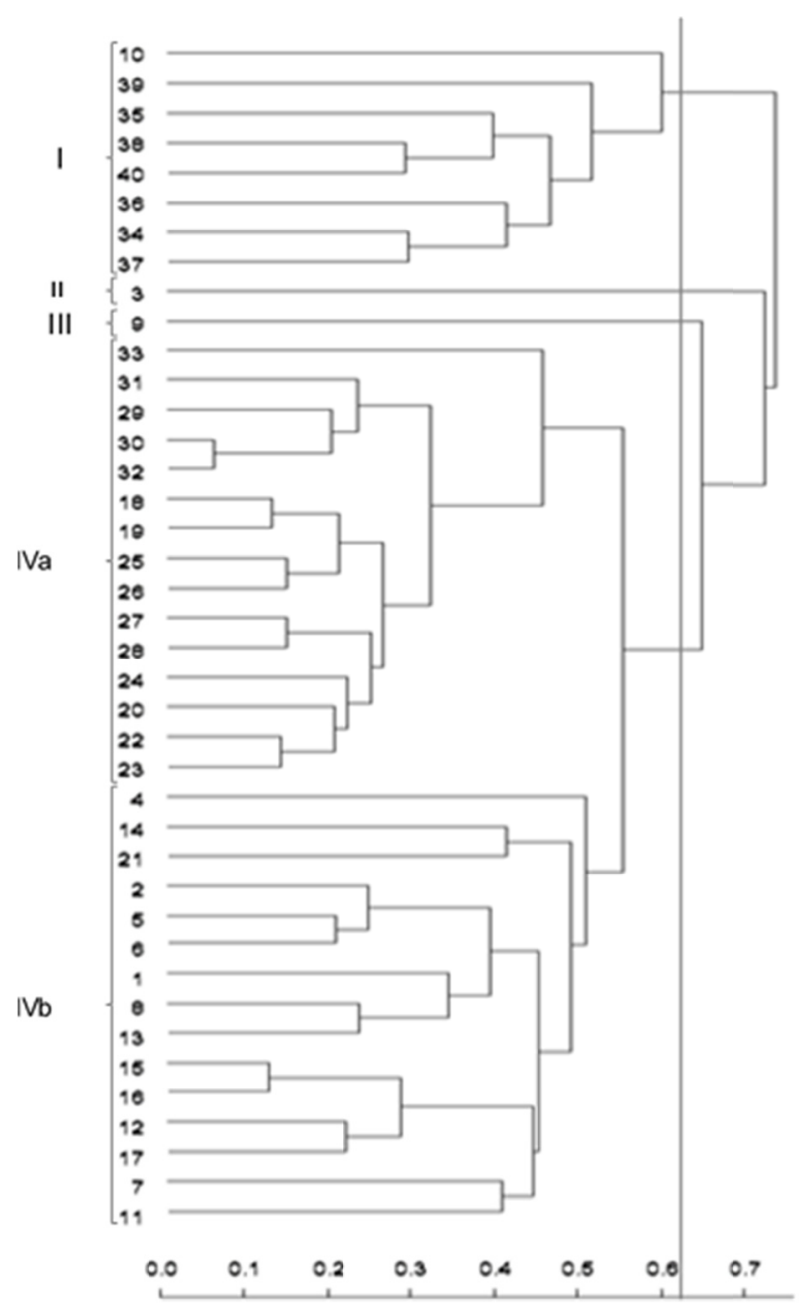

Figure 3. Dendrogram obtained by the UPGMA method, software R, representing the grouping of the 40 isolates of Ramulispora sorghi

The Tocher's optimization method, based on the dissimilarity expressed by the Coefficient of $\mathrm{Nei}$ and $\mathrm{Li}$, allowed the 40 isolates to be distributed in 10 different groups (Table 3). Group I was the most numerous, formed by 19 isolates, whereas group II was composed of 7 isolates. Group III presented 5 isolates. Groups IV and V were composed of only two isolates each, and groups VI, VII, VIII, IX and X composed of only 1 isolate. 
Table 3. Formation of the cluster generated by the Tocher's Optimization method based on the dissimilarity of the 40 isolates of Ramulispora sorghi obtained in saccharin sorghum and biomass sorghum in the harvests from 2015 to 2017 and isolated from Embrapa

\begin{tabular}{|c|c|c|}
\hline Group & Isolates/(Accesses) & $\%$ of isolates \\
\hline I & $\begin{array}{l}\mathrm{B} 105 / 15(30), \mathrm{B} 101 / 15(32), \mathrm{B} 226 / 15(29), \mathrm{B} 106 / 15(28), \mathrm{B} 106 / 16(23), \mathrm{B} 226 / 16(27), \\
\mathrm{B} 109 / 16(26), \mathrm{B} 117 / 16(25), \mathrm{B} 202 / 16(22), \mathrm{B} 122 / 16(24), \mathrm{B} 216 / 16(18), \mathrm{B} 107 / 15(20), \\
\mathrm{B} 114 / 16(19), \mathrm{B} 113 / 16(17), \mathrm{B} 120 / 15(31), \mathrm{B} 107 / 16(15), \mathrm{B} 105 / 16(13), \mathrm{B} 103 / 15(16), \mathrm{B} 118 / 16(6)\end{array}$ & 47.5 \\
\hline II & $\mathrm{B} 122 / 15$ (11), B122/16 (12), B131/16 (8),B319/16 (7), B111/16 (2), B311/16 (5), EMB03 (14) & 17.5 \\
\hline III & B206/17 (38), B209/17 (40), B104/17 (34), B115/17 (37), B201/17 (36) & 12.5 \\
\hline IV & $\mathrm{S} 326 / 15(1), \mathrm{B} 116 / 15(21)$ & 5.0 \\
\hline $\mathrm{V}$ & $\mathrm{B} 112 / 17(35), \mathrm{B} 225 / 17$ (39) & 5.0 \\
\hline VI & $\mathrm{B} 101 / 16(10)$ & 2.5 \\
\hline VII & $\mathrm{B} 115 / 16(4)$ & 2.5 \\
\hline VIII & S114/15 (33) & 2.5 \\
\hline IX & $\mathrm{B} 108 / 16(9)$ & 2.5 \\
\hline$X$ & $\mathrm{~S} 316 / 15$ (3) & 2.5 \\
\hline Total & 40 & 100.00 \\
\hline
\end{tabular}

Table 4 shows dissimilarity intragroups and intergroups, where the greatest intragroup distance was verified between groups IV and V (0.45), while the shortest distance was observed in group I (0.34). The greatest inter-group distances were between groups IX and VIII (0.84), both groups are formed by only one isolate, but, from plantations in different years. The lowest distances were recorded between groups VII and II (0.47) (Table 4). The first and second group allocated isolates from the years collected from 2015 and 2016, and in the second group there is the presence of the isolate from Embrapa.

Table 4. Average distance intragroup and intergroup estimated by the Tocher's optimization method based on dissimilarity among 40 isolates of Ramulispora sorghi

\begin{tabular}{|c|c|c|c|c|c|c|c|c|c|c|}
\hline & I & II & III & IV & V & VI & VII & VIII & IX & $X$ \\
\hline I & 0.3457 & 0.5276 & 0.7388 & 0.5236 & 0.7302 & 0.5738 & 0.599 & 0.5221 & 0.6618 & 0.762 \\
\hline II & & 0.4127 & 0.7483 & 0.5011 & 0.7969 & 0.5888 & 0.4784 & 0.7292 & 0.5648 & 0.6164 \\
\hline III & & & 0.3943 & 0.7535 & 0.4949 & 0.5834 & 0.6518 & 0.7824 & 0.8355 & 0.8119 \\
\hline IV & & & & 0.4546 & 0.6909 & 0.6705 & 0.6173 & 0.6928 & 0.5835 & 0.5242 \\
\hline $\mathrm{V}$ & & & & & 0.4546 & 0.6111 & 0.7023 & 0.7937 & 0.8019 & 0.8083 \\
\hline VI & & & & & & - & 0.6923 & 0.7037 & 0.6923 & 0.7222 \\
\hline VII & & & & & & & - & 1.00 & 0.6364 & 0.52 \\
\hline VIII & & & & & & & & - & 0.8462 & 1.00 \\
\hline IX & & & & & & & & & - & 0.7895 \\
\hline$X$ & & & & & & & & & & - \\
\hline
\end{tabular}

\section{Discussion}

Researching the genetic variability in $R$. sorghi, a fungus that causes the ramulispora spot in the sorghum crop, is still scarce, due to its being considered a disease of secondary importance (Brady et al., 2011; Little et al., 2018), however, the increase in incidence and severity of crops has aroused sorghum producers to better control, so the results obtained in this research have brought relevant information to the studies of this pathogen in sorghum genotypes and may help the breeding programs that aim to the development of cultivars genetically resistant to the fungus $R$. sorghi.

The studies that have the data measured in PIC indicate the number of alleles detected considering their distribution and frequency in the population, thus, the PIC is related to the number of alleles that is directly associated with the genetic divergence and the number of genotypes under study (Anderson et al., 1993). In this sense, the results obtained through the genetic analysis of the isolates of $R$. sorghi indicated the existence of genetic variability in the collected isolates, in the city of Cáceres, state of Mato Grosso. 
The molecular markers used in this study revealed the existence of genetic variability of the isolates, classified as medium information with an average value of 0.27 . Values ranged from 0.21 for primer AP4 to 0.33 for primers $(\mathrm{GTG})_{6}$ and AP1 (Table 1). According to Botstein et al. (1980) and Roldán-Ruiz et al. (2000), the PIC value of each marker represents the probability that the molecular marker is present or absent in two random individuals of the population. Thus, the PIC proves the existence of genetic variability, that is, the closer to 0.5 the PIC value, the greater the ability of the primer to differentiate individuals from a group, therefore, values lower than 0.25 are considered to be less informative, values from 0.26 to 0.49 are medium informative and values above 0.50 are considered highly informative.

Thus, the markers used for this study are in the range of results that contribute to the study of variability for this fungus. Xiang et al. (2016) studying 88 Lentinula edode isolates from four geographical regions of China found values ranging from 0.43 to 0.8 for PIC, showing great genetic variability among isolates, in this case, for different regions. In our study, there is genetic variability, according to the PIC values, even if they are isolated in the same region, Cáceres, demonstrated the great evolutionary capacity of the fungus $R$. sorghi. One of the ways in which fungi differ genetically is through their evolutionary process, that is, the generation of genetic variability in living beings is mainly due to its evolutionary process, adapting to different environments and hosts to survive (Taylor et al., 2000).

Analyzing the genetic variability of six isolates of Stenocarpella maydis by means of 42 molecular markers of the ISSR type, Fedrigo (2014), obtained a good amplification profile of the primers where PIC values ranged from 0.31 to 0.45 with mean value of 0.36. Patel et al. (2018), investigating isolates of Colletotrichum falcatum in sugarcane cultivars found the highest PIC value of 0.84 to 0.46 , with an average value of 0.76 for 21 markers of the ISSR type. The results found in all the studies, compared to the results of $R$. sorghi refer to the ISSR markers the ability to present the information of genetic divergence existing in a population.

The results of the population structure analysis for the 40 isolates of $R$. sorghi demonstrated in figure 2, presented the differentiation of the isolates in two distinct clusters. The subdivisions of the isolates are presented in the vertical lines that separate the individuals in the bar plot diagram, possible to observe that the columns of different colors indicate the different clusters. The introgressors represent the genetic similarity of the isolates of different colors in the same bar of the bar plot, corresponding to $35 \%$ of the total. These data show that there is a genetic dissimilarity among the studied isolates, although the collections were made in different years of cultivation and there is still an isolate coming from another place, these details allow to inquire if the isolates were transmitted initially through the seeds, because one of the most effective ways of disseminating this pathogen is through infected seeds and remaining mycelia from one crop to another (Brady et al., 2011; Little et al., 2018).

Considering the results obtained in this work, and comparing with the study developed by Li et al. (2016) in Colletotrichum fructicola isolates by means of the ISSR-type markers, it can be inferred that for these analyzes there were equal numbers of $\Delta \mathrm{K}$ groups formed, $\mathrm{K}=2$, but the total number of loci differed, 98 for the work developed by Li et al. (2016) and 71 in R. sorghi, this factor shows that although the number of loci obtained in $R$. sorghi was lower, the proportion of polymorphism obtained was not as discrepant considering the existence of 167 isolates of $C$. fructicola that were distributed in 15 geographic populations and a small cluster containing seven isolates from four plantations in four provinces. In this context, the R. sorghi fungus even with a lower population and only one collection region showed similar genetic variability with the work of Li et al. (2016), indicating that it is a pathogen with wide diversity, that is, great pathogenic variability.

The results obtained by Reis (2012) with isolates of Sporisorium scitamineum from different sugarcane regions found three clusters with the presence of 4 introgressors from the 14 isolates studied, corresponding to approximately $28 \%$ of the total. In this way, the values obtained by $\Delta \mathrm{K}$ shows the optimal amount of groups to be formed considering the genetic variability obtained with the analyzed data.

The genetic dissimilarity measures of the 40 isolates of $R$. sorghi, collected from Cáceres, were estimated from the Coefficient of Nei and Li (Table 2), where the combination between the isolates B107/16 (15) and B103/15 (16) presented the lowest magnitude of dissimilarity (0.12) and the combinations between isolates B111/16 (2) and S114/15 (33), S316/15 (3) and S114/15 (33), B115/16 (4) and S114/15 (33), B118/16 (6) and S114/15 (33) were more dissimilar (1.00). In the case of dissimilarity of isolates, Medeiros (2015), when studying the genetic diversity of 11 isolates of Thielaviopsis paradoxa in sugarcane stem from five Brazilian states, obtained the lowest magnitude of dissimilarity at 0.5 and the highest magnitude of dissimilarity at 0.86 . Considering these values, it can be inferred that the isolates of $R$. sorghi presented greater amplitude of dissimilarity (0.12 and 1.00) 
for the 40 isolates studied, indicating a wide genetic variability among the isolates, even though collected in the same region.

This fact can be explained by the fungus $R$. sorghi produce structures called sclerotia, which produce large numbers of spores that survive from one crop to another and can remain viable for more than 2 years in the crops, thus, these fungi present great evolutionary capacity (Brady et al., 2011). Studies by Kumata et al. (2009) indicated the presence of the casual agent of sooty stripe in crops in Nigeria, where it was highlighted as the sorghum disease with the highest incidence in the area. The disease has also been reported in studies carried out in Asia and the Americas, demonstrating its evolutionary capacity and increasing its incidence in sorghum crops around the world (Thomas et al., 1993; Brady et al., 2011; Goylit, 2016).

In the case of the UPGMA method, with results obtained by Silva (2009), from 147 isolates of Colletotrichum sublineolum in sorghum hybrids and considering the use of molecular markers of type ISSR, the number of groups formed was similar, six groups in the work with $C$. sublineolum while we obtained five in the study with $R$. sorghi. This information indicates that the isolates of $R$. sorghi, even though in a smaller number (40), were better distributed among the groups, showing that they were more genetically diverse.

This distance indicates the groups that are more dissimilar genetically and also, more similar. Comparing this distance the formation of the groups, it can be inferred that the groups IV and V, with a distance of 0.45 are formed by sampling years 2017 and 2015 and the group having more similarity, IX and VIII (0.84), consists of planting isolates 2015 and 2016. The data intragroup and intergroup dissimilarity for genetic analysis in plant pathogens using the Tocher's optimization method, tells us that the evaluation of the genetic variability of the material under study, and these data are derived from a matrix of dissimilarity, where the evaluation follows by means of criteria in which the average distance must be smaller than the average intergroup distance (Cruz, 2011). Thus, for plant breeding one of the main objectives is the specific choice of the parents, who must have the sources of resistance to the disease in question, that is, genotypes resistant to the greatest number of pathogens and/or races of the fungus (Reddy et al., 2006).

Despite being considered a secondary disease for sorghum cultivation, the sooty stripe has gained prominence among producers around the world, affecting different types of sorghum and occurring at all stages of the plant, causing damage that can cause up to plant death (Brady et al., 2011; Goylit, 2016; Little et al., 2018). In this scenario, many studies have been developed to evaluate the genetic variability of the fungus, aiming to identify sources of resistance and to guarantee greater yields in the crops (Kumata et al., 2009; Ramos et al., 2012; Cúdom et al., 2016; Goylit, 2016), but information about the pathogen is still scarce and more studies around the world are needed to ensure that sorghum breeding programs, disease information and more effective control measures.

\section{Conclusion}

The results indicated the existence of genetic variability among the isolates of Ramulispora sorghi collected in the city of Cáceres, MT, for the analysis methods used in this study.

The fungus Ramulispora sorghi, a causal agent of the sooty stripe in sorghum, has been recurring in different regions of Brazil and the world, and thus, larger studies with this pathogen become essential for more effective control measures.

\section{References}

Almorades, A., \& Hady, M. R. (2009). Production of bioethanol from sweet sorghum: A review. African Journal of Agricultural Research, 4(9), 772-780.

Ampl Software. (2015). Gel-Quantum Information. Retrieved from http://www.ampl.com.au/gelquant_home.htm

Anderson, J. A., Churchill, G. A., Autrique, J. E., Tanksley, S. D., \& Sorrells, M. E. (1993). Optimizing parental selection for genetic linkage maps. Genome, 36(1), 181-186. https://doi.org/10.1139/g93-024

Archana, B., Kini, K. R., \& Prakash, H. S. (2014). Genetic diversity and population structure among isolates of the brown spot fungus, Bipolaris oryzae, as revealed by inter-simple sequence repeats (ISSR). African Journal of Biotechnology, 13(2), 238-244.

Bandyopadhay, R. (2000). Sooty stripe. In R. A. Frederiksen (Ed.), Compendium of sorghum diseases (pp. 14-15). St. Paul: American Phytopathological Society.

Botstein, D., White, R. L., Skolnick, M., \& Davis, R. W. (1980). Construction of a genetic linkage map in man using restriction fragment length polymorphisms. American Journal of Human Genetics, 32(3), 314-331. 
Brady, C. R., Noll, L. W., Saleh, A. A., \& Little, C. R. (2011). Disease severity and microsclerotium properties of the sorghum sooty stripe pathogen Ramulispora sorghi. Plant Disease, 95(7), 853-859. https://doi.org/ 10.1094/PDIS-10-10-0742

CONAB (Companhia nacional de abastecimento). (2019). Observartório agrícola. Acompanhamento da safra brasileira de grãos (pp. 1-140). Acomp. Safra Bras. Grãos, Safra 2017/18-Sexto Levantamento, Brasília.

Cota, L. V., Silva, D. D., Costa, R. V., \& Ramos, T. C. D. A. (2013). Caracterização e identificação de Fontes de Resistência à Mancha Foliar Causada por Ramulispora sorghi em Genótipos de Sorgo. Embrapa, Boletim de Pesquisa e Desenvolvimento, 92, 4-19.

Cruz, C. D. (2006). Software Genes: Multivariate analysis and simulations (p. 175). Viçosa: Universidade Federal de Viçosa.

Cruz, C. D., Ferreira, F. M., \& Pessoni, L. A. (2011). Biometria aplicada ao estudo da diversidade genética (p. 620). Visconde do Rio Branco, MG: Suprema.

Cúndom, M. A., Namtz, Y., \& Gutiérrez, A. S. (2016). Ramulispora sorghi patógeno en cultivos de sorgo del NE de Argentina. Summa Phytopathologica, 42(2), 183-184. https://doi.org/10.1590/0100-5405/2113

Evanno, G., Regnaut, S., \& Goudet, J. (2005). Detecting the number of clusters of individuals using the software STRUCTURE: a simulation study. Molecular Ecology, 14(8), 2611-2620. https://doi.org/10.1111/j.1365294X.2005.02553.X

FAO. (2019). Food and agricultural commodities production. Faostat Database Gateway. Retrieved from http://faostat.fao.org/site/339/default.aspx

Fedrigo, K. (2014). Levantamento de fungos causadores de podridão de espiga em milho e variabilidade genética em Stenocarpella maydis (Master Dissertation in Agronomy, Universidade Estadual do Centro-Oeste, Guarapuava, Paraná, Brazil).

Ferreira, A. S., Casela, C. R., \& Pinto, N. F. J. A. (2007). Manejo de doenças na cultura do sorgo (p. 89). Sete Lagoas. Embrapa Milho e Sorgo, Circular Técnica.

Gonçalves, D. L., Ambrozio, V. C., Barelli, M. A. A., Neves, L. G., Sobrinho, S. P., Luz, P. B., \& Silva, C. R. (2014). Genetic divergence of access through traditional bean characteristics of the seed. Bioscience Journal, 30(6), 1671-1681.

Gooding, G. V., \& Lucas, G. B. (1959). Factors influencing sporangial formation and zoospore activity in Phytophthora parasitica var. nicotianae. Phytopathology, 49, 277-281.

Goylit, H. (2016). Study on sooty stripe of sorghum (Ramulispora sorghi) (Doctoral Thesis in Agriculture, Plant Pathology, College of Agriculture, Indore, India).

Kumata, A. S., Aliyu, B. S., \& Emechebe, A. M. (2009). A survey of sorghum downy mildew in sorghum in the Sudano-sahelian savanna zones of Nigeria. Bayero Journal of Pure and Applied Sciences, 2(2), 218-222.

Li, H., Zhou, G. Y., Liu, J. A., \& Xu, J. (2016). Population Genetic Analyses of the Fungal Pathogen Colletotrichum fructicola on Tea-Oil Trees in China. PLoS ONE, 11(6), 0156841. https://doi.org/10.1371/ journal.pone.0156841

Little, C. R., Perumal, R., Ciampitti, I., \& Prasad, V. (2018). The biolgy and control of sorghum diseases. Sorghum: State of the Art and Future Perspective. American Society of Agronomy and Crop Science of America, USA. https://doi.org/10.2134/agronmonogr58.2015.0073

Medeiros, C. C. P. (2015). Diversidade genética de isolados de Thielaviopsis paradoxa em cana-de-açúcar (Master Dissertation in Agronomy, Universidade Estadual Paulista, Jaboticabal, São Paulo, Brazil).

Neumann, M., Restle, J., \& Brondani, I. L. (2004). Avaliação de silagens de sorgo (Sorghum bicolor, L. Moench) ou milho (Zea mays, L.) na produção do novilho superprecoce. Revista Brasileira de Milho e Sorgo, 3(3), 438-452. https://doi.org/10.18512/1980-6477/rbms.v3n3p438-452

Nghia, N. A., Kadir, J., Sunderasan, E., \& Abdullah, M. P. (2008). Morphological and Inter Simple Sequence Repeat (ISSR) markers analyses of Corynespora cassiicola isolates from rubber plantations in Malaysia. Mycopathologia, 166(4), 189-201. https://doi.org/10.1007/s11046-008-9138-8

Nida, H., Girma, G., Mekonen, M., Lee, S., Seyoum, A., Dessalegn, K., .. Mengiste, T. (2019). Identification of sorghum grain mold resistance loci through genome wide association mapping. Journal of Cereal Science, 85, 295-304. https://doi.org/10.1016/j.jcs.2018.12.016 
Olive, L. S., Lefebvre, C. L., \& Sherwini, H. S. (1946). The fungus that causes sooty stripe of soghum spp. Phytopathology, 36, 190-200.

Oliveira, C. R. R. (2015). Resistência de mamoeiro a pinta-preta e variabilidade genética de Asperisporium caricae (SPEG.) MAUBL (Doctoral Thesis in Genetics and Plant Breeding, Universidade Estadual do Norte Fluminense, Campos dos Goytacazes, Rio de Janeiro, Brazil).

Patel, P., Rajkumar, B. K., Parmar, P., Shah, R., \& Krishnamurthy, R. (2018) Assessment of genetic diversity in Colletotrichum falcatum Went accessions based on RAPD and ISSR markers. Journal of Genetic Engineering and Biotechnology, 16(1), 153-159. https://doi.org/10.1016/j.jgeb.2017.11.006

Pritchard, J., Stephens, M., \& Donnelly, P. (2000). Inference of population structure using multilocus genotype data. Genetics, 155(2), 945-959.

Ramos, T. C. D. A., Cota, L. V., Silva, D. D., Costa, R. V., Lanza, F. E., Nicoli, A., .. Marcondes, M. (2012). Resistência do sorgo a Ramulispora sorghi. XXIX Congresso Nacional de Milho e Sorgo, Águas de Lindóia, São Paulo, Brazil.

Reddy, B. V. S., Sharma, H. C., Thakur, R. P., Ramesh, S., Rattunde, F., \& Mgonja, M. (2006). Sorghum hybrid parents research at ICRISAT_-Strategies, status and impacts. Journal of SAT Agricultural Research, 2(1), $1-24$.

Reis, G. V. (2012). Diversidade genética de isolados do fungo Sporisorium scitamineum analisada através de fingerprinting da região telomérica (Master Dissertation in Agronomy, Escola Superior de Agricultura Luiz de Queiroz, Piracicaba, São Paulo, Brazil).

Rezende, R. K. S., Paiva, L. V., Paiva, R., Halfun-Júnior, A., \& Torga, P. P. (2009). Divergência genética entre cultivares de gérbera utilizando marcadores RAPD. Ciência Rural, 39(8), 2435-2440. https://doi.org/ $10.1590 / \mathrm{S} 0103-84782009005000176$

Ribas, P. M. (2008). Cultivo do sorgo. Retrieved from http://www.cnpms.embrapa.br/publicacoes/sorgo_4_ed/ plantio-plantio.html

Roldán-Ruiz, I., Dendauw, J., Bockstaele, E. V., Depicker, A., \& Loose, M. (2000). AFLP markers reveal high polymorphic rates in ryegrasses (Lolium spp.). Molecular Breeding, 6(2), 125-134. https://doi.org/10.1023/ A:1009680614564

Silva, B. M., Rossi, A. A. B., Dardengo, J. F. E., Araujo, V. A. A. C., Rossi, F. S., Oliveira, L. O., \& Clarindo, W. R. (2016). Diversidade genética estimada com marcadores entre sequências simples repetidas em cultivos comerciais de Cupuaçuzeiro. Ciência Rural, 46(1), 108-113. https://doi.org/10.1590/0103-8478cr20141634

Silva, D. D. (2009). Resistência de híbridos de sorgo e diversidade de Colletotrichum sublineolum (Doctoral Thesis in Phytopathology, Universidade Federal de Lavras, Lavras, Minas Gerais, Brazil).

Silva, J. L. L. (2016). Relato de mancha de ramulispora em sorgo no município de Cáceres-MT (Agronomy Monograph, Universidade do Estado de Mato Grosso, Cáceres, Mato Grosso, Brazil).

Talamini, V., Souza, E. A., Pozza, E. A., Silva, G. F., Ishikawa, F. H., \& Camargo-Júnior, O. A. (2006). Genetic Divergence Among and Within Colletotrichum lindemuthianum Races Assessed by RAPD. Fitopatologia Brasileira, 31(6), 545-550. https://doi.org/10.1590/S0100-41582006000600002

Taylor, J. W., Jacobson, D. J., Kroken, S., Kasuga, T., Geiser, D. M., Hibbet, D. S., \& Fisher, M. C. (2000). Phylogenetic species recognition and species concepts in fungi. Fungal Genetics and Biology, 31, 21-32. https://doi.org/10.1006/fgbi.2000.1228

Teixeira, A. M., Ribeiro, G. O. J., Velasco, F. O., \& Faria, W. G. J. (2014). Intake and digestibility of sorghum (Sorghum bicolor, L. Moench) silages with diferente tannin contentes in sheep. Revista Brasileira de Zootecnia, 43(1), 14-19. https://doi.org/10.1590/S1516-35982014000100003

Thomas, M. D., Bocoum, F., \& Thera, A. (1993). Field inoculations of sorghum with sclerotia and conidia of Ramulispora sorghi formed in vivo. Mycologia, 85(5), 807-810. https://doi.org/10.1080/00275514.1993. 12026336

Williams, R. J., Frederiksen, R. A., \& Girard, J. C. (1978). Sorghum and pearl millet disease identification handbook (No. 2, pp. 2-88). International Crops Research Institute for the Semi-Arid Tropics. 
Xiang, X., Li, C., Li, L., Bian, Y., Kwan, H. S., Nong, W., Cheung, M. K., \& Xiao, Y. (2016). Genetic diversity and population structure of Chinese Lentinula edodes revealed by InDel and SSR markers. Mycological Progress, 15-37. https://doi.org/10.1007/s11557-016-1183-y

\section{Copyrights}

Copyright for this article is retained by the author(s), with first publication rights granted to the journal.

This is an open-access article distributed under the terms and conditions of the Creative Commons Attribution license (http://creativecommons.org/licenses/by/4.0/). 